\title{
IL6 and CRP haplotypes are associated with COPD risk and systemic inflammation: a case-control study
}

\author{
Dilyara G Yanbaeva*1, Mieke A Dentener ${ }^{1}$, Martijn A Spruit ${ }^{2}$, \\ Jeanine J Houwing-Duistermaat ${ }^{3}$, Daniel Kotz ${ }^{4}$, Valéria Lima Passos ${ }^{5}$ and \\ Emiel FM Wouters 1,2
}

\begin{abstract}
Address: ${ }^{1}$ Department of Respiratory Medicine, Nutrition and Toxicology Research Institute Maastricht (NUTRIM), Maastricht University Medical Centre, Maastricht, The Netherlands, ${ }^{2}$ Department of Research, Development \& Education, Centre for Integrated Rehabilitation of Organ failure (CIRO), Horn, The Netherlands, ${ }^{3}$ Department of Medical Statistics and Bioinformatics, Leiden University Medical Centre, Leiden, The Netherlands, ${ }^{4}$ Department of General Practice, School for Public Health and Primary Care (CAPHRI), Maastricht University Medical Centre, Maastricht, The Netherlands and ${ }^{5}$ Methodology \& Statistics Department, Maastricht University Medical Centre, Maastricht, the Netherlands

Email: Dilyara G Yanbaeva* - d.yanbaeva@pul.unimaas.nl; Mieke A Dentener - mieke.dentener@pul.unimaas.nl; Martijn A Spruit - martijnspuit@proteion.nl; Jeanine J Houwing-Duistermaat - j.j.houwing@lumc.nl; Daniel Kotz - d.kotz@hag.unimaas.nl; Valéria Lima Passos - valeria.limapassos@stat.unimaas.nl; Emiel FM Wouters - e.wouters@lung.azm.nl

* Corresponding author
\end{abstract}

Published: 9 March 2009

BMC Medical Genetics 2009, 10:23 doi:10.1 186/1471-2350-10-23
Received: 30 September 2008

Accepted: 9 March 2009

This article is available from: http://www.biomedcentral.com/I47/-2350/I0/23

(c) 2009 Yanbaeva et al; licensee BioMed Central Ltd.

This is an Open Access article distributed under the terms of the Creative Commons Attribution License (http://creativecommons.org/licenses/by/2.0), which permits unrestricted use, distribution, and reproduction in any medium, provided the original work is properly cited.

\begin{abstract}
Background: Elevated circulating levels of C-reactive protein (CRP), interleukin (IL)-6 and fibrinogen $(\mathrm{FG})$ have been repeatedly associated with many adverse outcomes in patients with chronic obstructive pulmonary disease (COPD). To date, it remains unclear whether and to what extent systemic inflammation is primary or secondary in the pathogenesis of COPD.

The aim of this study was to examine the association between haplotypes of CRP, IL6 and FGB genes, systemic inflammation, COPD risk and COPD-related phenotypes (respiratory impairment, exercise capacity and body composition).

Methods: Eighteen SNPs in three genes, representing optimal haplotype-tagging sets, were genotyped in 355 COPD patients and 195 healthy smokers. Plasma levels of CRP, IL-6 and FG were measured in the total study group. Differences in haplotype distributions were tested using the global and haplotype-specific statistics.

Results: Raised plasma levels of CRP, IL-6 and fibrinogen were demonstrated in COPD patients. However, COPD population was very heterogeneous: about $40 \%$ of patients had no evidence of systemic inflammation (CRP $<3 \mathrm{mg} / \mathrm{uL}$ or no inflammatory markers in their top quartile). Global test for haplotype effect indicated association of CRP gene and CRP plasma levels $(P=0.0004)$ and IL6 gene and COPD $(P=0.003)$. Subsequent analysis has shown that IL6 haplotype $H 2$, associated with an increased COPD risk ( $p=0.004, O R=4.82 ; 1.64$ to 4.18 ), was also associated with very low CRP levels $(P=0.0005)$. None of the genes were associated with COPD-related phenotypes.
\end{abstract}

Conclusion: Our findings suggest that common genetic variation in CRP and IL6 genes may contribute to heterogeneity of COPD population associated with systemic inflammation. 


\section{Background}

Chronic obstructive pulmonary disease (COPD) is a multi-component respiratory disease with recognized systemic impact [1]. Numerous studies performed in recent years provide overwhelming evidence of COPD as a condition characterized by an abnormal inflammatory response beyond the lungs with evidence of low-grade systemic inflammation [2-5]. Raised levels of acute phase proteins like C-reactive protein (CRP), fibrinogen and pro-inflammatory cytokines such as interleukin (IL)-6 were found in circulation of stable COPD patients $[3,6]$ and have been shown to be associated with impaired functional capacity [7], reduced daily physical activity [8] and decreased health status $[5,7,9]$. However, given the cross-sectional nature of most studies performed so far and possible confounding by a number of lifestyle factors associated with levels of inflammatory biomarkers [10], it is not clear whether these proteins are simply markers of the inflammatory process accompanying chronic diseases such as COPD or key players in the pathogenesis of disease.

Genome-wide scans, twin and family studies have shown that circulating levels of CRP, fibrinogen and IL- 6 are heritable (estimated as 25\%-40\%) [11-15]. Furthermore, recently $C R P$ and FGB polymorphisms/haplotypes have been described that may partly explain heritability of acute-phase protein and cytokine levels [16-19]. Genetic association testing of genotypes, which influence circulating levels of proteins and directly relate to the outcome of interest, was suggested as more accurate unconfounded estimate of whether systemic inflammation levels causally influence outcome [20].

In the present study we investigate whether common haplotypes in CRP, IL6 and FGB (encoding fibrinogen $\beta$ chain) genes influence systemic inflammatory status in COPD, the risk for COPD and, eventually, different disease-related phenotypes. Some of the results of this study have been previously reported in the form of an abstract [21].

\section{Methods Study participants}

The investigation was designed as a case-control association study, consisting of unrelated individuals recruited from the same geographical area (Limburg province, the Netherlands). A total of 556 Caucasian subjects were investigated. All subjects were current or former smokers. Three hundred and sixty-one patients with clinically stable moderate-to severe COPD entering pulmonary rehabilitation (Center for Integrated Rehabilitation of Organ failure (CIRO), Horn, The Netherlands) were enrolled for the study. Clinical history of COPD and the degree of the disease severity were assessed according to the published
Global Initiative for Chronic Obstructive disease (GOLD) guidelines [22]. One hundred and ninety five healthy (ex) smokers were recruited as controls. The healthy control subjects were volunteers recruited through advertisement in a local newspaper. Part of the healthy controls were also recruited through the COSMO study [23]. Inclusion criteria for both groups were: Caucasian origin, 40 years of age or older, smoking history of 10 pack-years or more, completed spirometry and blood sample donation. The ethical review board of the University Hospital Maastricht approved the study, and all subjects gave their written informed consent.

\section{Clinical examination and inflammation measurement}

Lung function was determined using spirometry, height and weight were measured in every participant and body mass index was calculated. Several COPD-related clinical characteristics were assessed only in COPD patients based on standard procedures (see Additional file 1). Plasma levels of CRP, IL- 6 and fibrinogen were measured by highsensitivity particle-enhanced immunoassay, ELISA and coagulation reaction respectively. Further details are provided in Additional file 1.

\section{TagSNP selection and genotype determination}

TagSNPs were selected for genotyping from the SeattleSNPs database http://gvs.gs.washington.edu/GVS/ using resequencing data from 23 unrelated European Americans. Polymorphisms with a minor allele frequency of less $5 \%$ were not included. Six polymorphisms in CRP, 8 SNPs in IL6 and 6 SNPs in FGB were selected. For two nonredundant SNPs of FGB the development of the genotyping assay failed (rs2227432, rs2227439), leaving 4 tagSNPs for the analysis. For further details on DNA processing and genotyping see Additional file 1.

\section{Statistical analysis \\ Descriptive statistics and baseline comparisons}

Variables are presented as proportions (percentage), mean \pm standard deviation (SD) or median (range) depending on their measurement scale and distribution. Plasma levels of inflammatory mediators were skewed to the right. They were natural logarithmically transformed to achieve symmetric distribution. Baseline differences between groups were analyzed using Student's $t$ test and MannWhitney test for continuous variables and $\chi^{2}$ square test for categorical variables. Prevalence of systemic inflammation has been accessed by number of inflammatory markers in the top quartile and by CRP levels. The correlations between inflammatory markers and the different clinical phenotype were estimated using Pearson's or Spearman's correlation coefficient. Multiple linear regression models were performed to search for the best predictors of CRP, IL-6 and fibrinogen levels. 


\section{Genetic association analysis}

To determine the linkage disequilibrium (LD) we have calculated the D' statistics between SNPs. Hardy-Weinberg equilibrium for each tagSNP was tested by the exact $\chi^{2}$ statistic. SNP rs2069849 in IL6 was excluded from haplotype analysis because of low allele frequency (3\%). To reduce the problem of multiple testing we selected haplotypes as major genetic variable. Differences in haplotype distributions were tested using the global statistic of Schaid under additive genetic model [24]. If the global haplotype test achieved a P-value $<0.1$, haplotype-specific analysis was performed. Haplotype-specific effects were estimated using linear and logistic regression as implemented in the haplo.stats package in R. Analyses were adjusted for potentially confounding factors (see Additional file 1 for full description). P-values less than 0.05 were considered significant (two-sided).

Eight primary genetic tests were performed. First, each gene was tested for association with two major outcomes: either corresponding protein level or COPD. These comprised 6 tests. Additionally, given that IL- 6 is a major regulator of hepatic production of CRP and fibrinogen, we also investigated the association of IL6 haplotypes with $\mathrm{CRP}$ and fibrinogen plasma levels (2 tests). To reduce the problem of spurious associations due to multiple testing, Bonferroni correction was applied for those tests $\left(P_{\text {corrected }}\right.$ $=0.05 / 8$ tests $=0.006)$.

Body-Mass Index, Airflow Obstruction, Dyspnea, and Exercise Capacity (BODE) index, 6 minute walking distance (6MWD), maximum workload at the cardiopulmonary test, Medical research council (MRC) score, body mass index (BMI) and forced expiratory volume in $1 \mathrm{sec}$ (FEV1) were tested after initial 8 analyses have been performed and treated as secondary outcomes. Secondary COPD outcomes were not considered for a conservative Bonferonni correction, because of a high degree of correlation with each other.

\section{Results}

\section{Systemic inflammation}

Table 1 summarizes the demographic data and baseline characteristics of study groups. Compared with the healthy smokers, COPD patients were older, more likely to be men and had more pack-years smoking. On average, patients had moderate-to-severe airflow obstruction and clear functional exercise intolerance.

In general, COPD patients had higher baseline median levels of circulating inflammatory markers $(P<0.001)$ (Table 1). This difference was still significant after adjustment for age, sex, smoking status, BMI and pack-years smoked. However, the COPD population was very heterogeneous: $27.3 \%$ of COPD patients had CRP levels > 10 $\mathrm{mg} / \mathrm{L}$, which is a significantly higher proportion than in healthy smokers $(5.2 \%)$, whereas about $40 \%$ of COPD patents had no evidence of systemic inflammation as assessed by CRP levels alone $(<3 \mathrm{mg} / \mathrm{L})$ or by the number of inflammatory markers in their top quartiles (no markers in the top quartile).

Table 2 shows the comparison of clinical characteristics from patients with baseline CRP value $<3 \mathrm{mg} / \mathrm{L}$ versus $>$ $3 \mathrm{mg} / \mathrm{L}$. Patients from the "inflammatory" group (CRP > 3 $\mathrm{mg} / \mathrm{L}$ ) were older, more likely to be male, had a higher BMI, more co morbidities and worse results in the 6 minute walking test. Interestingly, besides age and sex, the 6MWD was negatively associated with all 3 inflammatory markers in the backward multiple linear regression analyses (see Additional file 2). Correlations between the inflammatory markers and the functional measures of disease are shown in Additional file 3.

\section{Haplotype Tagging SNPs and COPD}

From the data of SeattleSNPs, we selected 18 SNPs (Table 3 ) which together tag the 5 most common (frequency > $2.5 \%$ ) haplotype groups of CRP, the 8 most common haplotype groups of IL 6 and the 5 most common haplotype groups of FGB (Table 4). None of the tagSNPs showed a significant deviation from Hardy-Weinberg in a control group, and the allele frequencies were comparable to those reported in the Seattle SNP panel and other Caucasian populations and individuals of Dutch origin $[18,19,25]$. All polymorphisms within each gene showed a little evidence of historical recombination as measured by D' (see Additional file 4).

Table 3 shows basic characteristics for SNPs and their allele frequency distribution in COPD patients and healthy smokers. Significant difference in allele frequency between patients and controls was found for the CRP synonymous SNP 2667G/C (rs1800947) and for the IL6 3'UTR SNP 7592G/A (rs1818879). Results of single-SNP analyses performed for all 18 SNPs for each of the major outcome are summarized in Table 3 and Additional file 5. Briefly, an increased risk of COPD was found for carriers of the minor alleles of the rs 1800947 and rs1818879. For the tri-allelic CRP SNP rs3091244, association with increased CRP levels was observed. We also identified two CRP and one IL6 SNPs, which were significantly associated with decreased CRP levels (see Additional file 5).

\section{Haplotype-based analysis, COPD and systemic inflammation phenotypes in COPD patients}

Common haplotypes were predicted from genotypic data. First, global test for haplotype association were performed for all 3 genes to provide an overall test with 4 outcomes of interest (Table 4). A significant difference in haplotype distribution between patients and controls was observed 
Table I: Baseline characteristics of COPD patients and healthy controls*

\begin{tabular}{|c|c|c|c|}
\hline Characteristics & $\begin{array}{l}\text { Controls } \\
N=195\end{array}$ & $\begin{array}{c}\text { COPD } \\
N=355\end{array}$ & $P$-value \\
\hline Years of age & $54.3(7.3)$ & $64.2(9.4)$ & $<0.001$ \\
\hline Male, N (\%) & $94(48)$ & $219(62)$ & 0.002 \\
\hline Current smoker, $\mathrm{N}(\%)$ & II $15(59 \%)$ & $90(25 \%)$ & $<0.001$ \\
\hline Tobacco consumption, pack years-smoked & $29.6(14.8)$ & $39.9(18.5)$ & $<0.001$ \\
\hline FEVI, liters & $3.2(0.7)$ & $\mathrm{I} . \mathrm{I}(0.5)$ & $<0.001$ \\
\hline FEVI,\%pred & $103.3(15.1)$ & $41.9(16.0)$ & $<0.001$ \\
\hline FEVI/FVC, \% & $78.3(5.3)$ & $42.0(11.9)$ & $<0.001$ \\
\hline FVC, liters & $4.1(0.9)$ & $3.0(0.9)$ & $<0.001$ \\
\hline FVC,\%pred & $109.3(16.8)$ & $86.3(21.1)$ & $<0.001$ \\
\hline BMI, kg/m2 & $26.4(3.7)$ & $25.0(5.0)$ & $<0.001$ \\
\hline Hypertensiont, N (\%) & $33(17 \%)$ & $88(25 \%)$ & 0.01 \\
\hline $\mathrm{PaO} 2, \mathrm{kPa}$ & - & $9.2(1.37)$ & \\
\hline $\mathrm{PaCO} 2, \mathrm{kPa}$ & - & $5.5(0.80)$ & \\
\hline Long-term oxygen therapy, $\mathrm{N}(\%)$ & - & $82(23.43)$ & \\
\hline 6 minute walking distance, meters & - & $420.1(127.9)$ & \\
\hline Maximum workload, watts & - & $72.6(33.9)$ & \\
\hline Maximum workload,\% pred & - & $56.6(25.2)$ & \\
\hline MRC dyspnea score & - & $3(2-4)$ & \\
\hline BODE index & & $4.3(2.1)$ & \\
\hline Systolic blood pressure, $\mathrm{mm} / \mathrm{Hg}$ & - & $135.9(23.31)$ & \\
\hline Diastolic blood pressure, $\mathrm{mm} / \mathrm{Hg}$ & - & $81.1(13.09)$ & \\
\hline Charlson co morbidity index $\ddagger$ & - & $I(I-8)$ & \\
\hline $\mathrm{CRP}, \mathrm{mg} / \mathrm{L}$ & $1.3(0.2-3.19)$ & $4.6(1.3-11.09)$ & $<0.001$ \\
\hline $\mathrm{IL}-6, \mathrm{pg} / \mathrm{mL}$ & $0.7(0.45-1.38)$ & $2.1(1.15-4.24)$ & $<0.001$ \\
\hline Fibrinogen, $g / L$ & $3.3(3.00-3.60)$ & $3.6(3.23-3.82)$ & $<0.001$ \\
\hline $\begin{array}{l}\text { Number of plasma markers } \\
\text { in the top quartile: }\end{array}$ & & & $<0.001$ \\
\hline $0, N(\%)$ & $155(79.4 \%)$ & $159(44.5 \%)$ & \\
\hline $\mathrm{I}, \mathrm{N}(\%)$ & $29(14.4 \%)$ & $88(24.2 \%)$ & \\
\hline $2-3, N(\%)$ & $10(5.2 \%)$ & $118(31.3 \%)$ & \\
\hline $\mathrm{CRP}<\mathrm{I} \mathrm{mg} / \mathrm{L}$ & $93(47.9 \%)$ & 68 (19.2\%) & $<0.001$ \\
\hline CRP I-3 mg/L & $51(26.3 \%)$ & $81(22.8 \%)$ & \\
\hline CRP 3-10 mg/L & $40(20.6 \%)$ & $109(30.7 \%)$ & \\
\hline CRP $>10 \mathrm{mg} / \mathrm{L}$ & $10(5.2 \%)$ & 97 (27.3\%) & \\
\hline
\end{tabular}

*Data presented as mean (standard deviation), median (inter quartile range) or No (\%) unless otherwise stated †Hypertension was defined as blood pressure $>140 / 90 \mathrm{mmHg}$ or need for antihypertensive treatment.

$\ddagger$ Median (range)

for ILG $(\mathrm{P}=0.003)$. There was a trend for association with COPD for CRP haplotypes $(\mathrm{P}=0.09)$. At the same time, CRP levels were the most significantly associated with CRP haplotypes $(\mathrm{P}=0.0004)$ and less strongly with IL6 haplotypes $(\mathrm{P}=0.08)$ (Table 4$)$.

To investigate the cause of these associations further we calculated haplotype-specific scores and then estimated haplotype effects relative to the most common haplotype when all haplotypes were entered into regression model (Tables 5, 6). In particular, CRP haplotype H3 was associated with higher risk of being COPD and low CRP levels when tested against the most common haplotype $\mathrm{H} 4$ (Table 5). However, IL6 haplotype $\mathrm{H} 2$ was associated with even higher decrease in CRP levels (Table 6). Moreover, the IL6 haplotype $\mathrm{H} 2$ was differently distributed between cases and controls (6.2\% versus $2.4 \%, \mathrm{P}=0.0006)$ and associated with almost 5 times higher risk of COPD compared to the most common haplotype H4 (OR $=4.82$, 95\%CI 1.64-4.18, $\mathrm{P}=0.004$ ) (Table 6). Thus, the H2 haplotype effect on COPD risk is stronger than the effect of the IL6 rs1818879 (OR = 1.49, 95\%CI 1.08-2.04) (Table 3).

Comparable associations were found when the total group of cases and controls was considered for analysis of systemic inflammation levels $(\mathrm{N}=550)$ (data not shown).

\section{Genetic variation and COPD-related phenotypes}

Given that inflammatory markers were correlated with some disease characteristics (see Additional file 3), we further studied whether corresponding inflammatory genes are associated with important quantitative COPD phenotypes and performed the association analysis for 6 out- 
Table 2: Comparison of clinical parameters between patients with initial CRP levels $\leq 3 \mathrm{mg} / \mathrm{L}$ versus $>3 \mathrm{mg} / \mathrm{L}$

\begin{tabular}{|c|c|c|c|}
\hline Characteristics & $\begin{array}{c}C R P \quad 3 \mathrm{mg} / \mathrm{L} \\
N=146\end{array}$ & $\begin{array}{c}C R P>3 \mathrm{mg} / \mathrm{L} \\
N=209\end{array}$ & $P$-value \\
\hline Years of age & $62.1(8.2)$ & $65.7(9.8)$ & $<0.001$ \\
\hline Male, N (\%) & 77 (53\%) & 142 (68\%) & 0.004 \\
\hline Current smoker, N (\%) & $40(27 \%)$ & $50(24 \%)$ & 0.460 \\
\hline Tobacco consumption, pack years-smoked & $40.3(19.0)$ & $39.6(18.2)$ & 0.703 \\
\hline FEVI, liters & $\mathrm{I} . \mathrm{I}(0.5)$ & $\mathrm{I} . \mathrm{I}(0.5)$ & 0.922 \\
\hline FEVI,\%pred & $41.6(15.9)$ & $41.9(15.9)$ & 0.846 \\
\hline FEVI/FVC, \% & $41.0(11.8)$ & $42.7(11.8)$ & 0.172 \\
\hline FVC, liters & $3.0(1.0)$ & $3.0(0.9)$ & 0.884 \\
\hline FVC,\%pred & $87.5(22.5)$ & $85.4(20.3)$ & 0.373 \\
\hline $\mathrm{BMI}, \mathrm{kg} / \mathrm{m} 2$ & $24.0(4.4)$ & $25.7(5.4)$ & 0.001 \\
\hline $\mathrm{PaO} 2, \mathrm{kPa}$ & $9.3(1.5)$ & $9.1(1.3)$ & 0.259 \\
\hline $\mathrm{PaCO} 2, \mathrm{kPa}$ & $5.4(0.8)$ & $5.5(0.8)$ & 0.342 \\
\hline Long-term oxygen therapy, $\mathrm{N}(\%)$ & $30(21 \%)$ & $52(25 \%)$ & 0.205 \\
\hline 6 minute walking distance, meters & $445.9(121.2)$ & $401.1(129.3)$ & 0.001 \\
\hline Maximum workload, watts & $77.2(34.7)$ & $69.2(33.0)$ & 0.037 \\
\hline Maximum workload,\% pred & $57.4(23.6)$ & $56.0(26.4)$ & 0.636 \\
\hline MRC dyspnea score & $2(2-4)$ & $3(2-4)$ & 0.108 \\
\hline BODE index & $4.1(2.1)$ & $4.4(2.1)$ & 0.264 \\
\hline Systolic blood pressure, $\mathrm{mm} / \mathrm{Hg}$ & $134.7(2 \mid .7)$ & $136.8(24.4)$ & 0.412 \\
\hline Diastolic blood pressure, $\mathrm{mm} / \mathrm{Hg}$ & $80.7(12.5)$ & $81.4(13.5)$ & 0.647 \\
\hline Charlson co morbidity index $\dagger$ & $I(I-7)$ & $I(I-8)$ & 0.007 \\
\hline \multicolumn{4}{|l|}{ GOLD stages (\%): } \\
\hline Mild & $2.1 \%$ & $2.4 \%$ & 0.891 \\
\hline Moderate & $27.4 \%$ & $23.9 \%$ & \\
\hline Severe & $35.6 \%$ & $38.3 \%$ & \\
\hline Very severe & $34.9 \%$ & $35.4 \%$ & \\
\hline CRP, mg/L & I.I (0.6-1.9) & $9.4(5.8-16.0)$ & $<0.001$ \\
\hline $\mathrm{IL}-6, \mathrm{pg} / \mathrm{mL}$ & $1.3(0.7-2.1)$ & $3.5(1.6-5.1)$ & $<0.001$ \\
\hline Fibrinogen, $g / L$ & $3.3(3.0-3.6)$ & $3.7(3.4-4.0)$ & $<0.001$ \\
\hline
\end{tabular}

*Data presented as mean (standard deviation), median (inter quartile range) or No (\%) unless stated otherwise † Median (range)

comes: BODE index, MRC score, $\mathrm{BMI}_{1} \mathrm{FEV}_{1}$, maximum workload and 6MWD. For all 3 genes, no significant association was observed when an overall test of association was applied, except for a marginal association of the CRP gene and maximum workload (Table 7). Further testing showed borderline association of the haplotype 121211 with maximum workload $(\mathrm{P}=0.05)$.

\section{Discussion}

Similar to previous studies [4,9], we have shown that circulating levels of CRP, IL- 6 and fibrinogen are increased in clinically stable COPD patients comparing to healthy (ex)smokers. Importantly, inflammatory markers distribution has shown a striking heterogeneity of COPD population in relation to the systemic inflammatory response. Furthermore, we observed a significant association between IL6 and CRP haplotypes and CRP levels in COPD patients as well as in the total study group, similar to the previous population-based and clinical studies $[16,26,27]$. Surprisingly, in our study those haplotypes were not related to any of COPD functional phenotype including BMI and 6MWD, which were the most strongly correlated with CRP plasma levels similar to the previous reports $[4,5,9]$. However, when compared to the controls, a new association of IL6 gene and COPD was identified. In particular, IL6 haplotype $\mathrm{H} 2$ (6.2\% of cases) was associated with 5 times higher risk of COPD and significant decrease in CRP levels in COPD patients. To our knowledge, the present study is the first haplotype-based association analysis examining common genetic variation in CRP, IL 6 and FGB genes on COPD risk and circulating levels of inflammatory markers in COPD patients and healthy smokers.

Although presence of systemic inflammation has been widely accepted in the last years as an essential characteristic of COPD $[3,28]$, our data clearly show that levels of CRP and 2 other widely studied in COPD markers, IL-6 and fibrinogen, vary significantly across the COPD population. This gives us strong evidence that not all COPD patients have a manifested low-grade systemic inflammatory response. In fact, comparable findings was reported in our previous study of CRP in relation to COPD phenotypes [7]. Further evidence of heterogeneity in relation to 
Table 3: Tagging SNPs characteristics and single SNP association analysis for COPD

\begin{tabular}{|c|c|c|c|c|c|c|c|}
\hline \multirow[t]{2}{*}{ dbSNP No. } & \multirow[t]{3}{*}{ tagSNP* } & \multirow[t]{3}{*}{ Gene region } & \multicolumn{2}{|c|}{ Minor allele frequency } & \multirow[t]{2}{*}{$P$-value allelest } & \multirow{3}{*}{$\begin{array}{c}\text { OR a adj } \neq \text { genotypes } \\
(95 \% \mathrm{Cl})\end{array}$} & \multirow[t]{2}{*}{$P$-value genotypes } \\
\hline & & & Controls & COPD & & & \\
\hline \multicolumn{5}{|c|}{ IL6 gene (7p2 I-p | 5) } & & & \\
\hline rs2069825 & $205 \mathrm{CT} /-$ & 5'flanking & 0.42 & 0.37 & 0.11 & $\begin{array}{c}0.87 \\
(0.64-1.17)\end{array}$ & 0.35 \\
\hline rs2069827 & $321 \mathrm{G} / \mathrm{T}$ & 5'flanking & 0.10 & 0.07 & 0.10 & $\begin{array}{c}0.67 \\
(0.39-1.14)\end{array}$ & 0.14 \\
\hline rs 1800797 & I086G/A & 5'flanking & 0.44 & 0.39 & 0.12 & $\begin{array}{c}0.86 \\
(0.64-1.16)\end{array}$ & 0.32 \\
\hline rs2069840 & $3437 C / G$ & intron & 0.34 & 0.36 & 0.52 & $\begin{array}{c}1.04 \\
(0.76-1.42)\end{array}$ & 0.81 \\
\hline rs 1554606 & $3572 \mathrm{G} / \mathrm{T}$ & intron & 0.46 & 0.42 & 0.19 & $\begin{array}{c}0.84 \\
(0.62-1.13)\end{array}$ & 0.25 \\
\hline rs2069849 & $602 \mathrm{IC} / \mathrm{T}$ & synonymous & 0.03 & 0.02 & 0.33 & $\begin{array}{c}0.51 \\
(0.19-1.36)\end{array}$ & 0.18 \\
\hline rs206986I & $6519 \mathrm{C} / \mathrm{T}$ & 3'flanking & 0.11 & 0.09 & 0.24 & $\begin{array}{c}0.93 \\
(0.57-1.52)\end{array}$ & 0.77 \\
\hline rs 1818879 & $7592 \mathrm{G} / \mathrm{A}$ & 3'flanking & 0.32 & 0.39 & 0.02 & $\begin{array}{c}1.49 \\
(1.08-2.04)\end{array}$ & 0.01 \\
\hline \multicolumn{8}{|c|}{ CRP gene (Iq2I-q23) } \\
\hline \multirow[t]{2}{*}{ rs309/244 } & $1440 \mathrm{C} / \mathrm{T}$ & 5'flanking & 0.30 & 0.31 & 0.08 & $\begin{array}{c}1.01 \\
(0.73-1.40)\end{array}$ & 0.94 \\
\hline & $1440 \mathrm{C} / \mathrm{A}$ & & 0.06 & 0.08 & & $\begin{array}{c}1.57 \\
(0.88-2.79)\end{array}$ & 0.12 \\
\hline rs 1800947 & $2667 \mathrm{G} / \mathrm{C}$ & synonymous & 0.05 & 0.08 & 0.03 & $\begin{array}{c}1.80 \\
(0.96-3.37)\end{array}$ & 0.06 \\
\hline rsII30864 & $3014 \mathrm{C} / \mathrm{T}$ & 3' UTR & 0.30 & 0.31 & 0.65 & $\begin{array}{c}1.05 \\
(0.76-1.46)\end{array}$ & 0.76 \\
\hline rs 1205 & $3872 \mathrm{G} / \mathrm{A}$ & 3'-flanking & 0.35 & 0.33 & $0.4 I$ & $\begin{array}{c}0.98 \\
(0.73-1.32)\end{array}$ & 0.91 \\
\hline rs 2808630 & $5237 \mathrm{~A} / \mathrm{G}$ & 3'-flanking & 0.29 & 0.27 & 0.55 & $\begin{array}{c}0.83 \\
(0.60-1.15)\end{array}$ & 0.27 \\
\hline rs3090077 & $6469 \mathrm{~A} / \mathrm{C}$ & 3'-flanking & 0.05 & 0.08 & 0.15 & $\begin{array}{c}1.59 \\
(0.86-2.96)\end{array}$ & 0.14 \\
\hline \multicolumn{8}{|c|}{ FGB gene $(4 q 28)$} \\
\hline rs|80079| & I038G/A & 5' flanking & 0.18 & 0.17 & 0.63 & $\begin{array}{c}0.80 \\
(0.55-1.18)\end{array}$ & 0.26 \\
\hline rs 1800788 & $1643 \mathrm{C} / \mathrm{T}$ & 5' flanking & 0.18 & 0.21 & 0.31 & $\begin{array}{c}1.36 \\
(0.94-1.95)\end{array}$ & 0.10 \\
\hline rs|800787 & $1744 \mathrm{C} / \mathrm{T}$ & 5' flanking & 0.21 & 0.20 & 0.59 & $\begin{array}{c}1.10 \\
(0.75-1.61)\end{array}$ & 0.62 \\
\hline rs222742I & $9952 \mathrm{~A} / \mathrm{C}$ & 3' UTR & 0.31 & 0.33 & 0.59 & $\begin{array}{c}1.03 \\
(0.74-1.42)\end{array}$ & 0.87 \\
\hline
\end{tabular}

\footnotetext{
* TagSNPs are numbered by position in sequences AF4497I 3 for CRP, AF3722I 4 for IL6 and AF388026 for FGB. Base change common allele/rare allele.

$\dagger P$ value is for the test of allele counting in cases versus controls.

‡ Logistic regression analysis was adjusted for age, sex and tobacco consumption (pack-years smoked)
}

CRP comes from a recent intervention study [29], which has shown that COPD patients segregate for provastatinresponders (CRP > $1 \mathrm{mg} / \mathrm{uL}$ ) and non-responders (CRP < $1 \mathrm{mg} / \mathrm{L}$ ) based on their baseline CRP levels. Those nonresponders may represent the distinct COPD subpopulation with low CRP levels which has impaired immune response to bacteria, viruses and other agents. Interestingly, our findings also suggest that low CRP levels may be associated with significantly higher COPD risk in carriers of a specific IL6 haplotype. Given that lung-expressed CRP could be up regulated by cytokines and has shown cyto- protective effect in innate immune response against bacteria and particulate matter [30-32], CRP and IL6 haplotypes should be further studied in relation to the local impairment in COPD.

In previous reports there seems to be inconsistency about the relationship involving biomarkers levels, corresponding genes and COPD phenotypes. On the one hand, significant associations between the plasma levels of CRP, IL6 and fibrinogen and COPD phenotypes have been observed $[2,7,8,33]$. Yet, on the other, no relationship 
Table 4: Frequency distribution in patients and controls and global association tests for haplotypes of IL6, CRP and FGB

\begin{tabular}{|c|c|c|c|c|c|c|c|}
\hline \multirow[t]{2}{*}{ Gene } & \multirow[t]{2}{*}{ Haplotype* } & \multirow{2}{*}{$\begin{array}{c}\text { Controls } \\
\%\end{array}$} & \multirow{2}{*}{$\begin{array}{c}\text { COPD } \\
\%\end{array}$} & \multicolumn{4}{|c|}{ Global test P-valuest } \\
\hline & & & & COPD & $\begin{array}{l}\operatorname{Ln} \\
(\mathrm{IL}-6)\end{array}$ & $\begin{array}{l}\operatorname{Ln} \\
\text { (CRP) }\end{array}$ & $\begin{array}{c}\operatorname{Ln} \\
\text { (fibrinogen) }\end{array}$ \\
\hline \multirow[t]{7}{*}{ IL6 } & $\mathrm{HI} I I I I I I I$ & 17.8 & 16.1 & 0.003 & 0.80 & 0.08 & 0.73 \\
\hline & $\mathrm{H} 2 \mathrm{IIIIII}$ & 2.4 & 6.2 & & & & \\
\hline & $\mathrm{H} 3 \mathrm{III} I 1 \mathrm{I}$ & 4.8 & 10.2 & & & & \\
\hline & $\mathrm{H} 4 \mathrm{II} 12 \mathrm{II}$ & 27.8 & 25.0 & & & & \\
\hline & $\mathrm{H} 52121211$ & 20.1 & 16.1 & & & & \\
\hline & $\mathrm{H} 62121221$ & 10.4 & 7.7 & & & & \\
\hline & H7 222121। & 10.1 & 6.3 & & & & \\
\hline \multirow[t]{5}{*}{$C R P$} & $\mathrm{HI} \mid \mathrm{III} I$ & 28.7 & 26.6 & 0.09 & Not tested & 0.0004 & Not tested \\
\hline & $\mathrm{H} 2 \mathrm{II} 121 \mathrm{I}$ & 30.3 & 24.2 & & & & \\
\hline & $\mathrm{H} 3121211$ & 4.9 & 8.2 & & & & \\
\hline & $\mathrm{H} 4212111$ & 29.7 & 30.4 & & & & \\
\hline & $\mathrm{H} 5311112$ & 5.4 & 7.3 & & & & \\
\hline \multirow[t]{5}{*}{$F G B$} & $\mathrm{HI} I \mathrm{II}$ & 11.9 & 10.3 & 0.28 & Not tested & Not tested & 0.72 \\
\hline & $\mathrm{H} 2 \mathrm{II} / 2$ & 31.2 & 32.8 & & & & \\
\hline & $\mathrm{H} 3 \mathrm{II} 2 \mathrm{I}$ & 21.0 & 19.2 & & & & \\
\hline & $\mathrm{H} 4 \mathrm{I} 2 \mathrm{I}$ & 18.2 & 20.9 & & & & \\
\hline & H5 2111 & 17.4 & 16.2 & & & & \\
\hline
\end{tabular}

\footnotetext{
* I codes the common allele and 2 codes the minor allele. IL6 loci are presented in the order rs2069825, rs2069827, rs |800797, rs2069840, rs I554606, rs206986 I and rs I8I8879. CRP loci are presented in the order rs309|244, rs I800947, rs I I30864, rs I 205, rs2808630 and rs3090077. FGB loci are presented in the order rs I80079I, rs I800788, rs I800787 and rs222742 I

† Global test p-value from haplo.score for overall association between haplotypes and trait. The COPD analysis was adjusted for age, sex and tobacco consumption (pack-years smoked). Inflammatory markers levels analyses were adjusted for marker-specific clinical covariates: age, sex and 6MWD (all genes) and BMI (only for CRP).
}

between the polymorphisms influencing the protein levels and COPD phenotypes could be demonstrated in the current and some other smaller studies [34,35]. Interestingly, three recent mRNA/protein profiling studies in quadriceps and vastus lateralis of COPD patients [36-38] failed to confirm a common hypothesis that increased expression of pro-inflammatory cytokines (IL-6, IL-8, IL-1 and TNF- $\alpha$ ) induce muscle atrophy in COPD patients with muscle weakness. Several phenomena might explain differences between studies of inflammatory genes,

Table 5: Association of CRP haplotypes with COPD and In(CRP)

\begin{tabular}{ccccc}
\hline & COPD* & \multicolumn{3}{c}{$\operatorname{Ln}(C R P) \dagger$} \\
\hline Haplotype & OR $(95 \% \mathrm{Cl})$ & P-value & Coefficient \pm SE & P-value \\
\hline HI & $0.85(0.57-1.27)$ & 0.42 & $-0.33 \pm 0.13$ & 0.01 \\
H2 & $0.86(0.64-1.16)$ & 0.43 & $-0.13 \pm 0.13$ & 0.34 \\
H3 & I.64 (0.83-3.27) & 0.16 & $-0.58 \pm 0.20$ & 0.004 \\
H4 & REFERENT & & REFERENT & \\
H5 & I.35 (0.69-2.65) & 0.38 & $-0.02 \pm 0.21$ & 0.92 \\
Others $\neq$ & $2.91(0.77-0.98)$ & 0.12 & $0.66 \pm 0.27$ & 0.01
\end{tabular}

* Logistic regression analyses were adjusted for age, sex and tobacco consumption (pack-years smoked).

† Linear regression analyses were adjusted for age, sex, BMI and 6MWD.

$\ddagger$ Rare haplotypes (frequency $<2.5 \%$ ) were coded in aggregate as "others"
mRNA and proteins in COPD. It is well-known that results of observational studies of inflammatory markers might be confounded because of residual association with numerous non-diseases related factors (i.e. lifestyle and socioeconomic) $[10,39]$. Thus, association of CRP or IL6 variation with disease phenotype may suggest a causal relationship between CRP levels and disease [20]. However, genetic variation in CRP actually only explains a rel-

Table 6: Association of IL6 haplotypes with COPD and In(CRP)

\begin{tabular}{ccccc}
\hline & COPD * & \multicolumn{2}{c}{$\operatorname{Ln}(\mathrm{CRP}) \dagger$} \\
\hline Haplotype & OR $(95 \% \mathrm{Cl})$ & P-value & Coefficient \pm SE & P-value \\
\hline HI & $0.92(0.56-1.5 \mathrm{I})$ & 0.75 & $0.005 \pm 0.17$ & 0.98 \\
H2 & $4.82(1.64-4.18)$ & 0.004 & $-0.94 \pm 0.27$ & 0.0005 \\
H3 & I.7I (0.85-3.44) & 0.13 & $-0.12 \pm 0.21$ & 0.54 \\
H4 & REFERENT & \multicolumn{3}{c}{ REFERENT } \\
H5 & I.0I (0.64-I.60) & 0.95 & $0.01 \pm 0.17$ & 0.93 \\
H6 & $0.93(0.51-1.67)$ & 0.80 & $-0.36 \pm 0.22$ & 0.10 \\
H7 & $0.71(0.37-1.36)$ & 0.3 & $-0.02 \pm 0.24$ & 0.94 \\
Others $\neq$ & I.48(0.79-2.78) & 0.22 & $-0.07 \pm 0.20$ & 0.73
\end{tabular}

* Logistic regression analyses were adjusted for age, sex and tobacco consumption (pack-years smoked).

† Linear regression analyses were adjusted for age, sex, BMI and 6MWD.

$\ddagger$ Rare haplotypes (frequency $<2.5 \%$ ) were coded in aggregate as "others" 
Table 7: COPD-related phenotypes and global association tests (P-values) for haplotypes of IL6, CRP and FGB

\begin{tabular}{lcccccc}
\hline & \multicolumn{5}{c}{ Phenotype* } \\
\cline { 2 - 6 } Gene & BODE index & MRC score & 6MWD, meters & Maximum workload, Watts & BMI, Kg/m2 & FEVI, L \\
\hline IL6 & 0.38 & 0.41 & 0.48 & 0.81 & 0.06 \\
CRP & 0.33 & 0.41 & 0.11 & 0.06 & 0.22 \\
FGB & 0.74 & 0.61 & 0.61 & 0.64 & 0.70 \\
\hline
\end{tabular}

*Global association tests were adjusted for marker-specific clinical covariates selected by backward linear regression. Age and sex were included in all final models.

Other covariates included in regression models per phenotype:

BODE index: smoking status (former/current), $\mathrm{P}_{\mathrm{CO} 2}(\mathrm{kPa})$

MRC score: FEV, (liters), smoking status (former/current)

6MWD: FEV (liters), Charlson co morbidity index, diastolic blood pressure, smoking status (former/current).

Maximum workload: $F E V_{1}$ (liters), Charlson co morbidity index, diastolic blood pressure, $\mathrm{P}_{\mathrm{CO} 2}(\mathrm{kPa})$, height.

BMI: FEV (liters), smoking status (former/current), diastolic blood pressure, PCO2 ( $\mathrm{kPa})$

$\mathrm{FEV}_{1}$ : Height, systolic and diastolic blood pressure, $\mathrm{P}_{\mathrm{CO} 2}(\mathrm{kPa})$ and $\mathrm{P}_{\mathrm{O} 2}(\mathrm{kPa})$.

atively small proportion of CRP levels variation $(<3 \%)$, compared with other environmental or genetic factors $[16,26,40]$. Moreover, given the fact that COPD might share systemic inflammatory phenotype with cardiovascular disease, cancer and diabetes [41,42], which are known co morbidities of COPD, conflicting association data may be caused by different composition of the COPD populations used across different studies. Lastly, acutephase and pro-inflammatory cytokine genes may be only modifiers of other, not widely studied, inflammatory genes, which are critically involved in COPD pathogenesis. Further hypothesis-free genome-wide high-throughput screening and gene expression profiling studies are needed to validate existing and find new candidate markers characterizing distinct clinical profiles of multi-faced COPD population.

Our study has several strengths. It is the first one that has been specifically designed to evaluate relationship between systemic inflammation and COPD on both genetic and protein level. For this purpose, both standard outcomes (COPD diagnosis and lung function) as well as functional disease-related phenotypes (exercise capacity and body composition) were taken into account. We used a tagging SNP based approach capturing all common variability across the genes of interest to investigate whether genetic variation in the genes of interest influences the risk of COPD. Next this study is based on a well-characterized ethnically homogeneous cohort of stable COPD patients and spirometry-proved healthy smokers collected from the same geographic region.

In our analysis of 3 genes in relation to 4 primary outcomes it is possible but unlikely that results were false positives obtained due to a type I error inflation. It is worth mentioning, two associations (IL6 haplotypes and COPD, global $P=0.003, C R P$ haplotypes and $\ln (\mathrm{CRP})$, global $P=0.0004)$ were still significant after applying the conservative Bonferroni correction. In addition, these associations remained also significant at $\mathrm{P}<0.002$ after permutation tests with at least 10000 simulations. Nevertheless, all reported associations between COPD and CRP and IL 6 genes require replication in other independent studies. Similar to our results, three previous studies of the IL6 gene could not find any association between COPD and the SNPs rs 1800795 and rs 1800797 [43-45]. Interestingly, a new association was found with the IL6 SNP rs1800796 in COPD patients from Spain [44]. Because of a low allele frequency in Europeans (4\%), this SNP was not selected for current study; however, further studies using large samples size of Dutch COPD patients are required to replicate this new association.

There are also some limitations of the present study. First, the patients with COPD included in the study were assessed to enter pulmonary rehabilitation and had predominantly moderate-to-severe stages of COPD. This could affect generalizability of our results. Next, a relatively small sample size could have underpowered some observed genetic associations. Namely, IL6 association with CRP levels and CRP association with COPD were marginally significant in the overall testing but have shown strong haplotype-specific effects in further analysis. Furthermore, as a result of the failure of 2 FGB tag SNPs for genotyping we were not able to discriminate one common (defined by rs2227439) and one rare (carrying the minor allele of rs2227432) haplotypes of the FGB gene [19]. They were non-discriminative from the FGB haplotypes 1111 and 1121, respectively.

It is also noticeable, that, although we found an increased risk of COPD for the IL6 $\mathrm{H} 2$ carriers, the functional SNP causing this risk still has to be identified. ILG haplotype $\mathrm{H} 2$ is tagged by the minor allele of rs 1818879 . However, it is unlikely, that this SNP located in 3'UTR region of ILG, is functional because no association between haplotype 
H4 (tagged by the combination of rs2069840 and rs1818879) and COPD risk was found. Most likely, the functional SNP lies on the IL6 H2 haplotype and was not genotyped in our study. Future resequencing of IL 6 haplotype H2 carriers may help to identify functional SNP(s). Given that a recent genome-wide association study [46] has found a SNP in IL-6 receptor gene as one of the top associated with six lung function phenotypes and the association we found between COPD and ILG gene, it would be worthwhile to study IL-6 pathway further [47].

\section{Conclusion}

In conclusion, CRP and IL6 haplotypes were shown to be associated with systemic inflammation and COPD but not with exercise capacity, dysnoea, BMI and BODE index. Future studies are needed to replicate the observed associations in large well-defined COPD cohorts.

\section{Abbreviations}

6MWD: Six Minute Walking Distance; BMI: Body Mass Index; BODE: Body-Mass Index, Airflow Obstruction, Dyspnea, and Exercise Capacity Index; CI: Confidence Interval; COPD: Chronic Obstructive Pulmonary Disease; CRP: C-Reactive Protein; dbSNP: NCBI Single Nucleotide Polymorphism Database; $\mathrm{FEV}_{1}$ : Forced Expiratory Volume in 1 Sec; FGB: Fibrinogen $\beta$; FVC: Forced Vital Capacity; IL6: Interleukin 6; LD: Linkage Disequilibrium; MRC: Medical Research Council; N: Number; OR: Odds Ratio; $\mathrm{Pa}_{\mathrm{CO} 2}$ : Carbon Dioxide Tension of Arterial Blood; $\mathrm{Pa}_{\mathrm{O} 2}$ : Oxygen Tension of Arterial Blood; SNP: Single Nucleotide Polymorphism; UTR: Untranslated Region.

\section{Competing interests}

Dr Yanbaeva has no conflicts of interest to disclose. Dr Dentener has no conflicts of interest to disclose. Dr Spruit has no conflicts of interest to disclose. Dr Houwing-Duistermaat has no conflicts of interest to disclose. Dr. Kotz has no conflicts of interest to disclose. Dr Lima Passos has no conflicts of interest to disclose. Prof Wouters is a member of the scientific advisory boards for GSK, Boehringer Ingelheim, AstraZeneca and Numico and received lecture fees from GSK, AstraZeneca, Boehringer Ingelheim. He received research grants between 2004 and 2007 from GSK, AstraZeneca, Boehringer Ingelheim, Centocor and Numico.

\section{Authors' contributions}

DY participated in the design of the study and control group recruitment, carried out genotyping, performed statistical analysis, was responsible for data integrity and drafted the manuscript. MD participated in the design and coordination of the study, supervised protein measurements, was responsible for the study documentation and helped to draft the manuscript. MS participated in the design of the study, coordinated patient recruitment and database maintenance. JJHD performed and coordinated the genetic statistical analysis. DK coordinated the control group recruitment. VLP performed and coordinated the statistical analysis. EFM conceived the study concept and design and supervised the study. All authors contributed to the manuscript revision, read and approved the final text.

\section{Additional material}

\section{Additional file 1}

The file has detailed description of the methods used in the study. Click here for file

[http://www.biomedcentral.com/content/supplementary/14712350-10-23-S1.pdf]

\section{Additional file 2}

Clinical predictors of plasma CRP, IL-6 and fibrinogen levels in COPD patients which retained in the best-fit multiple linear regression models.

Click here for file

[http://www.biomedcentral.com/content/supplementary/14712350-10-23-S2.pdf]

\section{Additional file 3}

Correlation between inflammatory markers and functional measures of disease

Click here for file

[http://www.biomedcentral.com/content/supplementary/1471-

2350-10-23-S3.pdf]

\section{Additional file 4}

Linkage disequilibrium structure at candidate genes.

Click here for file

[http://www.biomedcentral.com/content/supplementary/1471-

2350-10-23-S4.pdf]

\section{Additional file 5}

Association of IL6, CRP and FBG tagSNPs and multivariable adjusted CRP, IL-6 and fibrinogen levels in COPD patients

Click here for file

[http://www.biomedcentral.com/content/supplementary/14712350-10-23-S5.pdf]

\section{Acknowledgements}

The authors gratefully acknowledge Dr G.J. Wesseling (Department of Respiratory Medicine, Maastricht University Medical Center, Maastricht), Dr H-J. Pennings and A. van de Kruijs (both Centre for Integrated Rehabilitation of Organ failure, Horn), and J. Houben (Department of Health Risk Analysis and Toxicology, Maastricht University Medical Centre, Maastricht) for help with the control group recruitment. We also thank A. Derks (Centre for Integrated Rehabilitation of Organ failure, Horn) and N. Drummen (Department of Respiratory Medicine, Maastricht University Medical Centre) for assistance with blood processing, CRP and IL-6 measurements.

This study was supported by a grant of the European Respiratory Society (fellowship number 16I) and an unrestricted grant from Boehringer Ingelheim. 


\section{References}

I. GOLD: Executive Summary: Global Strategy for the Diagnosis, Management, and Prevention of COPD. Summary of GOLD recommendations for the diagnosis, management, and prevention of COPD, with citations from the scientific literature. 2006: I-32.

2. Donaldson GC, Seemungal TA, Patel IS, Bhowmik A, Wilkinson TM, Hurst JR, Maccallum PK, Wedzicha JA: Airway and systemic inflammation and decline in lung function in patients with COPD. Chest 2005, I 28(4): 1995-2004.

3. Gan WQ, Man SF, Senthilselvan A, Sin DD: Association between chronic obstructive pulmonary disease and systemic inflammation: a systematic review and a meta-analysis. Thorax 2004, 59(7):574-580.

4. Garrod R, Marshall J, Barley E, Fredericks S, Hagan G: The relationship between inflammatory markers and disability in chronic obstructive pulmonary disease (COPD). Prim Care Respir J 2007, I 6(4):236-240.

5. Pinto-Plata VM, Mullerova H, Toso JF, Feudjo-Tepie M, Soriano JB, Vessey RS, Celli BR: C-reactive protein in patients with COPD, control smokers and non-smokers. Thorax 2006, 6I(I):23-28.

6. Schols AM, Buurman WA, Staal van den Brekel AJ, Dentener MA Wouters EF: Evidence for a relation between metabolic derangements and increased levels of inflammatory mediators in a subgroup of patients with chronic obstructive pulmonary disease. Thorax 1996, 5 I (8):8I 9-824.

7. Broekhuizen R, Wouters EF, Creutzberg EC, Schols AM: Elevated CRP levels mark metabolic and functional impairment in advanced COPD. Thorax 2006, 6 I (I):17-22. Epub 2005 Jul 29

8. Watz H, Waschki B, Boehme C, Claussen M, Meyer T, Magnussen H: Extrapulmonary effects of chronic obstructive pulmonary disease on physical activity: a cross-sectional study. $\mathrm{Am} J$ Respir Crit Care Med 2008, I77(7):743-75I.

9. de Torres JP, Cordoba-Lanus E, Lopez-Aguilar C, Muros de Fuentes M, Montejo de Garcini A, Aguirre-Jaime A, Celli BR, Casanova C: Creactive protein levels and clinically important predictive outcomes in stable COPD patients. Eur Respir J 2006, 27(5):902-907.

10. Yarnell JW, Sweetnam PM, Rumley A, Lowe GD: Lifestyle factors and coagulation activation markers: the Caerphilly Study. Blood Coagul Fibrinolysis 200I, 1 2(8):72I-728.

II. de Maat MP, Bladbjerg EM, Hjelmborg JB, Bathum L, Jespersen J, Christensen K: Genetic influence on inflammation variables in the elderly. Arterioscler Thromb Vasc Biol 2004, 24(I I):2I68-2I73.

12. Dupuis J, Larson MG, Vasan RS, Massaro JM, Wilson PW, Lipinska I, Corey D, Vita JA, Keaney JF Jr, Benjamin E): Genome scan of systemic biomarkers of vascular inflammation in the Framing ham Heart Study: evidence for susceptibility loci on Iq Atherosclerosis 2005, 182(2):307-3/4.

13. Pankow JS, Folsom AR, Cushman M, Borecki IB, Hopkins PN, Eckfeldt $\mathrm{JH}$, Tracy RP: Familial and genetic determinants of systemic markers of inflammation: the NHLBI family heart study. Atherosclerosis 200I, I 54(3):68I-689.

14. Yang Q, Tofler GH, Cupples LA, Larson MG, Feng D, Lindpaintner K Levy D, D'Agostino RB, O'Donnell CJ: A genome-wide search for genes affecting circulating fibrinogen levels in the Framingham Heart Study. Thromb Res 2003, I I 0(I):57-64.

15. Hersh CP, Miller DT, Kwiatkowski DJ, Silverman EK: Genetic determinants of C-reactive protein in COPD. Eur Respir J 2006, 28(6): $1156-1162$

16. Lange LA, Carlson CS, Hindorff LA, Lange EM, Walston J, Durda JP, Cushman M, Bis JC, Zeng D, Lin D, et al.: Association of polymorphisms in the CRP gene with circulating C-reactive protein levels and cardiovascular events. Jama 2006 296(22):2703-27II.

17. Qi L, van Dam RM, Meigs JB, Manson JE, Hunter D, Hu FB: Genetic variation in IL6 gene and type 2 diabetes: tagging-SNP haplotype analysis in large-scale case-control study and metaanalysis. Hum Mol Genet 2006, I ( (I I):|9|4-1920.

18. Siemes C, Visser LE, Coebergh JW, Splinter TA, Witteman JC, Uitterlinden AG, Hofman A, Pols HA, Stricker BH: C-reactive protein levels, variation in the $C$-reactive protein gene, and cancer risk: the Rotterdam Study. / Clin Oncol 2006, 24(33):52 I 6-5222

19. Uitte de Willige S, de Visser MC, Houwing-Duistermaat J], Rosendaa $F R$, Vos HL, Bertina RM: Genetic variation in the fibrinogen gamma gene increases the risk for deep venous thrombosis by reducing plasma fibrinogen gamma' levels. Blood 2005 , 106(I3):4I76-4183.

20. Davey Smith G, Ebrahim S: 'Mendelian randomization': can genetic epidemiology contribute to understanding environmental determinants of disease? Int J Epidemiol 2003, 32(I): I-22.

21. Yanbaeva D, Dentener M, Spruit M, Kruijs A Van de, Derks A, Wouters $\mathrm{E}$ : Variation in C-reactive protein gene and COPD: tagging SNPs analysis in a case-control study. 17th ERS Annual Congress: September 15-19, 2007 2007; Stockholm, Sweden: Eur Respir J 2007:456s.

22. Rabe KF, Hurd S, Anzueto A, Barnes PJ, Buist SA, Calverley P, Fukuch Y, Jenkins C, Rodriguez-Roisin R, van Weel C, et al:: Global strategy for the diagnosis, management, and prevention of chronic obstructive pulmonary disease: GOLD executive summary. Am J Respir Crit Care Med 2007, I 76(6):532-555.

23. Kotz D, Wesseling G, Huibers MJ, van Schayck OC: Efficacy of confrontational counselling for smoking cessation in smokers with previously undiagnosed mild to moderate airflow limitation: study protocol of a randomized controlled trial. $B M C$ Public Health 2007, 7:332.

24. Schaid DJ, Rowland CM, Tines DE, Jacobson RM, Poland GA: Score tests for association between traits and haplotypes when linkage phase is ambiguous. Am J Hum Genet 2002, 70(2):425-434.

25. Reitz C, Berger K, de Maat MP, Stoll M, Friedrichs F, Kardys I, Witteman JC, Breteler MM: CRP gene haplotypes, serum CRP, and cerebral small-vessel disease: the Rotterdam Scan Study and the MEMO Study. Stroke 2007, 38(8):2356-2359.

26. Carlson CS, Aldred SF, Lee PK, Tracy RP, Schwartz SM, Rieder M, Liu K, Williams OD, Iribarren C, Lewis EC, et al.: Polymorphisms within the C-reactive protein (CRP) promoter region are associated with plasma CRP levels. Am J Hum Genet 2005, 77(I):64-77.

27. Miller DT, Zee RY, Suk Danik J, Kozlowski P, Chasman DI, Lazarus R, Cook NR, Ridker PM, Kwiatkowski DJ: Association of common CRP gene variants with CRP levels and cardiovascular events. Ann Hum Genet 2005, 69(Pt 6):623-638.

28. Walter RE, Wilk JB, Larson MG, Vasan RS, Keaney JF Jr, Lipinska I, O'Connor GT, Benjamin E): Systemic inflammation and COPD: the Framingham Heart Study. Chest 2008, I33(I):19-25.

29. Lee TM, Lin MS, Chang NC: Usefulness of C-reactive protein and interleukin-6 as predictors of outcomes in patients with chronic obstructive pulmonary disease receiving pravastatin. Am J Cardiol 2008, 10I(4):530-535.

30. Gould JM, Weiser JN: Expression of C-reactive protein in the human respiratory tract. Infect Immun 200I, 69(3): I747-I754.

3I. Dong Q, Wright JR: Expression of C-reactive protein by alveolar macrophages. J Immunol 1996, I 56(I 2):48I5-4820.

32. Ramage L, Proudfoot L, Guy K: Expression of C-reactive protein in human lung epithelial cells and upregulation by cytokines and carbon particles. Inhal Toxicol 2004, 16(9):607-6।3.

33. Yende S, Waterer GW, Tolley EA, Newman AB, Bauer DC, Taaffe DR, Jensen R, Crapo R, Rubin S, Nevitt M, et al.: Inflammatory markers are associated with ventilatory limitation and muscle dysfunction in obstructive lung disease in well functioning elderly subjects. Thorax 2006, 61 (1):10-16.

34. Broekhuizen R, Grimble RF, Howell WM, Shale DJ, Creutzberg EC, Wouters EF, Schols AM: Pulmonary cachexia, systemic inflammatory profile, and the interleukin Ibeta $-5 \mathrm{II}$ single nucleotide polymorphism. Am J Clin Nutr 2005, 82(5): I 059- 1064.

35. Hsieh MH, Chong IW, Hwang JJ, Lee CH, Ho CK, Yu ML, Huang CT, Lee CY, Wu MT, Christiani DC: Lack of associations between several polymorphisms in cytokine genes and the risk of chronic obstructive pulmonary diseases in Taiwan. Kaohsiung J Med Sci 2008, 24(3): I26-I37.

36. Crul T, Spruit MA, Gayan-Ramirez G, Quarck R, Gosselink R, Troosters T, Pitta F, Decramer M: Markers of inflammation and disuse in vastus lateralis of chronic obstructive pulmonary disease patients. Eur / Clin Invest 2007, 37( I I):897-904.

37. Debigare R, Maltais F, Cote CH, Michaud A, Caron MA, Mofarrahi M, Leblanc $P$, Hussain SN: Profiling of mRNA expression in quadriceps of patients with COPD and muscle wasting. Copd 2008, 5(2):75-84. 
38. Barreiro E, Schols AM, Polkey MI, Galdiz JB, Gosker HR, Swallow EB, Coronell C, Gea J: Cytokine profile in quadriceps muscles of patients with severe COPD. Thorax 2008, 63(2):100-107.

39. Tabassum F, Kumari M, Rumley A, Lowe G, Power C, Strachan DP: Effects of socioeconomic position on inflammatory and hemostatic markers: a life-course analysis in the 1958 British birth cohort. Am J Epidemiol 2008, I67(II):|332-I34I.

40. Crawford DC, Sanders CL, Qin X, Smith JD, Shephard C, Wong M, Witrak L, Rieder MJ, Nickerson DA: Genetic variation is associated with C-reactive protein levels in the Third National Health and Nutrition Examination Survey. Circulation 2006, I I 4(23):2458-2465.

41. Fabbri LM, Rabe KF: From COPD to chronic systemic inflammatory syndrome? Lancet 2007, 370(9589):797-799.

42. Sevenoaks MJ, Stockley RA: Chronic Obstructive Pulmonary Disease, inflammation and co-morbidity - a common inflammatory phenotype? Respir Res 2006, 7:70.

43. Broekhuizen R, Howell W, Shale D, Creutzberg EC, Wouters EF, Schols AM: Pulmonary cachexia, systemic inflammatory profile, and the interleukin Ibeta $-5 \mathrm{II}$ single nucleotide polymorphism. Am J Clin Nutr 2005, 82: 1059-1064.

44. Cordoba-Lanus EdTJ-P, Lopez-Aguilar, Rodriguez-Perez M-C, MacaMeyer N, Montejo-de-Garcini A, Aguirre-Jaime A, Perez-Mendez L Casanova C: Association of IL-6 gene polymorphism and COPD in a Spanish population. Respiratory Medicine 2008, I02:|805-|8||.

45. Seifart CDA, Plagens A, Seifart U, Clostermann U, Muller B, et al.: TNF-alpha, TNF-beta, IL-6, and IL- 10 promoter polymorphisms in patients with chronic obstructive pulmonary disease. Tissue Antigens 2005, 65:93-100.

46. Wilk JB, Walter RE, Laramie JM, Gottlieb DJ, O'Connor GT: Framingham Heart Study genome-wide association: results for pulmonary function measures. BMC Med Genet 2007, 8(Suppl I):S8.

47. Sin DDMS: Interleukin-6: a red herring or a real catch in COPD? Chest 2008, 133:4-6.

\section{Pre-publication history}

The pre-publication history for this paper can be accessed here:

http://www.biomedcentral.com/1471-2350/10/23/pre pub
Publish with Bio Med Central and every scientist can read your work free of charge

"BioMed Central will be the most significant development for disseminating the results of biomedical research in our lifetime. "

Sir Paul Nurse, Cancer Research UK

Your research papers will be:

- available free of charge to the entire biomedical community

- peer reviewed and published immediately upon acceptance

- cited in PubMed and archived on PubMed Central

- yours - you keep the copyright
BiolMedcentral 